\title{
Fertility in high-producing dairy cows: Reasons for decline and corrective strategies for sustainable improvement
}

\author{
MC Lucy \\ 158 Animal Sciences Research Center, University of Missouri, Columbia MO USA 65211
}

\begin{abstract}
The fertility of dairy cows has declined worldwide and this change is surprising given the importance of good fertility to the dairy industry. The decline in fertility can be explained by management changes within the dairy industry and also negative genetic correlations between milk production and reproduction. Four primary mechanisms that depress fertility in lactating cows are anovulatory and behavioral anestrus (failure to cycle and display estrus), suboptimal and irregular estrous cyclicity (this category includes ovarian disease and subnormal luteal function after breeding), abnormal preimplantation embryo development (may be secondary to poor oocyte quality), and uterine/placental incompetence. The solution for improving fertility in high-producing dairy cows will include both short-term and long-terms components. For the immediate short-term, using high fertility sires and implementing controlled breeding programs will help. Controlled breeding programs improve reproductive efficiency in confinement-style dairy herds and can be combined with post-insemination treatments to enhance fertility. An additional immediate short-term solution involves changing the diet so that dietary ingredients invoke hormonal responses that benefit the reproduction of the cow. The short-term solutions described above do not address the fundamental need for correcting the underlying genetics for reproduction in high-producing dairy cows. Crossbreeding will improve reproductive performance perhaps because it alleviates inbreeding and also lowers production in cows with an extreme high milk production phenotype. The current crisis in dairy reproduction will be permanently solved, however, when the genetics for dairy reproduction are improved through a balanced genetic selection strategy.
\end{abstract}

\section{Introduction}

Reproduction is important for sustainable dairying worldwide but reproductive efficiency has declined for dairy cows. Reproductive traits have low heritability so a major component of reproductive decline can be attributed to changes in the dairy industry (larger farms, lessskilled labor, etc.) that make reproductive management more difficult (Lucy 2001). Nonetheless, fertility breeding values for dairy cows have shown evidence of decline since 1957 (Lucy 
2005; data from United States dairy cows). The genetic decline in dairy fertility can be explained in part by negative genetic correlations between milk production and reproduction (Hansen 2000). One widely held theory is that the strategic use of adipose tissue for energy and milk substrates in early lactation leads to low postpartum body condition that in turn leads to poor reproductive performance (Lucy 2003; Pryce \& Harris 2006). The dissemination of highmilk producing genetics (predominately Holstein) from relatively few sire families led to a global problem in dairy reproduction (Lucy 2001). Reproductive decline is perhaps most acutely felt in seasonal pasture-based systems where non-pregnant cows are not carried over until the next calving season (Harris and Kolver 2001). Confinement-style dairy farmers that practice continuous calving also view reproduction as an area of concern (Lucy et al. 2004; Moore \& Thatcher 2006).

Reproductive rates are declining in lactating dairy cows but reproductive rates in dairy heifers (non-lactating) remain relatively high. A conception rate of $64 \%$ was found when over 330,000 inseminations to over 220,000 United States Holstein heifers were examined (January 2003 to October 2004; Kuhn \& Hutchinson 2005). The conception rate is considerably higher than the 20 to $40 \%$ conception rate typically reported for lactating cows in the United States. One conclusion from the Holstein heifer data is that the reproductive system of modern dairy cattle is essentially normal when lactation demands are not imposed. Perhaps unexpectedly, however, the same study found a positive association between heifer fertility and daughter pregnancy rate (DPR; the cow fertility trait used in the United States). Subsequent analyses have reported negative genetic correlations between heifer fertility and breeding values for lactation traits (milk, fat, and protein; VanRaden 2006). Failing to address the antagonistic genetic relationship between milk production traits and reproductive traits, therefore, will erode the fertility of both lactating cows and heifers.

\section{Four primary components of infertility in dairy cows}

Infertility in dairy cattle is multi-faceted and will require a holistic approach that addresses the problem. The scientific literature on dairy cow infertility is extensive. Indeed, the key words "dairy cow infertility" returned at least twice as many citations when compared to equivalent citations in other farm animals (Fig. 1). Dairy cattle, like any species, have a theoretical optimum for conception rate that is probably above $70 \%$ (a conception rate that can be achieved in dairy heifers selected for fertility; Andersen-Ranberg et al. 2005). Factors that impinge upon the lactating cow act collectively to decrease conception rate from the optimum (Fig. 2). Four primary mechanisms that depress fertility in lactating cows will be discussed herein. They are anovulatory and behavioral anestrus (failure to cycle and display estrus), suboptimal and irregular estrous cyclicity (this category includes ovarian disease and subnormal luteal function after breeding), abnormal preimplantation embryo development (may be secondary to poor oocyte quality), and uterine/placental incompetence. It is not surprising that reproduction is in decline when one considers that each of these primary components acting alone can cause infertility.

\section{Anovulatory and behavioral anestrus}

A period of anovulatory anestrus (ovarian follicular development without ovulation; also termed the anovulatory period) is normal for postpartum cows. In beef cows (considered highly fertile relative to dairy), suckling inhibits $\mathrm{LH}$ pulsatility and the lack of $\mathrm{LH}$ pulsatility leads to anovulatory anestrus (Williams \& Griffith 1995). As long as nutrition is adequate, the anestrous beef 


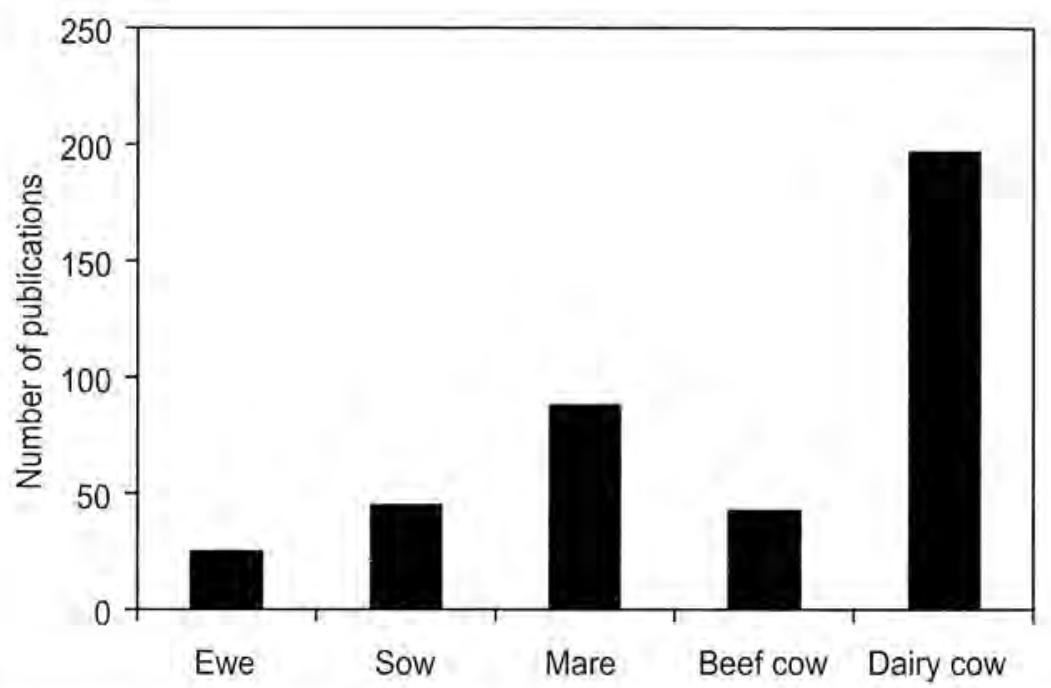

Fig. I. Number of scientific publications for "infertility" for different farm animal species retur ned in a June 2006 search of the PubMed scientific citation database (National Center for Biotechnology Information; National Library of Medicine, Bethesda, Maryland, USA).

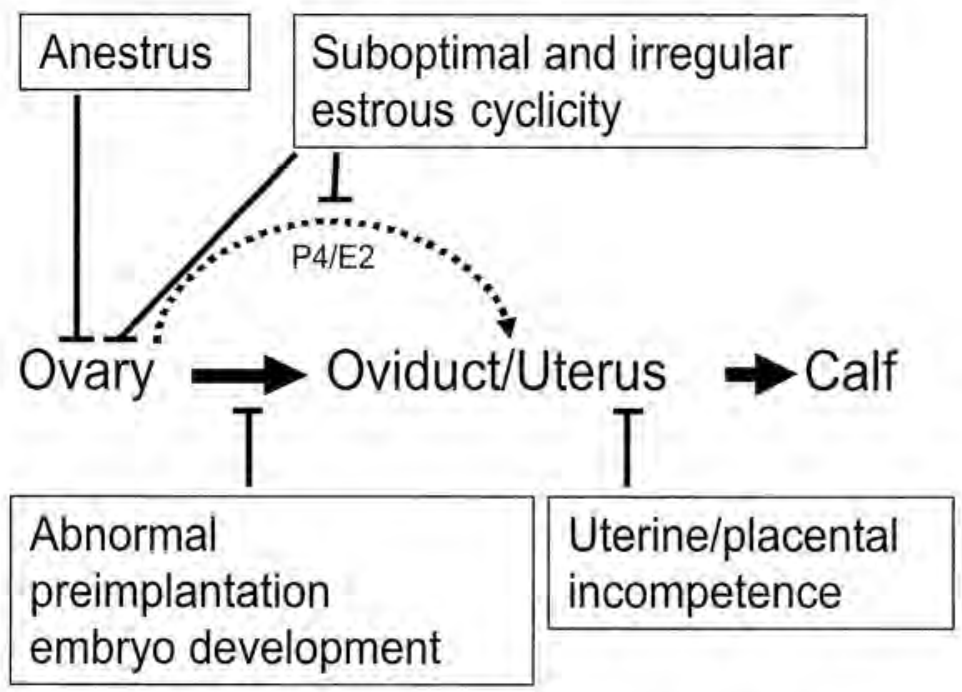

Fig 2. Four primary components of infertility in dairy cows (light gray boxes) that act at different levels of the reproductive process. The primary components act collectively to inhibit (blunt end lines) ovarian and oviductal/uterine function (see text for details). P4/E2 $=$ progesterone/estradiol.

cow is fertile once she starts cycling (Lucy et al. 2001). Likewise, New Zealand dairy cattle (grazing management system) are anestrus for longer than North American dairy cattle (confinement management system) but have better fertility (Meyer et al. 2004). Thus, the length of postpartum anovulatory anestrus per se may not be a major factor contributing to infertility of cattle unless the anestrus period extends into the breeding period. 
High-producing dairy cows have extended periods of anovulatory anestrus (Roche et al. 2000; Gong 2002; Lucy 2003). The anestrus is caused by negative energy balance that contributes to a hormonal milieu (low blood LH, insulin, and IGF-I) that is inadequate for preovulatory follicular development, the LH surge and ovulation (Lucy 2003). In dairy cows, anovulatory anestrus is symptomatic of a catabolic state (Beam \& Butler 1999). A benign state of anovulatory anestrus in beef cows and low-producing dairy cows is not the same biologically for high-producing dairy cows because the underlying causes of anestrus are different. Although a beef cow can be treated and recover from anestrus with normal fertility (Lucy et al. 2001), an anestrous dairy cow that is treated has lower fertility (Gumen et al. 2003) perhaps because her anestrum is a consequence of negative energy balance. Anovulatory anestrus can be treated with progestogen supplementation (Wiltbank et al. 2002; Rhodes et al. 2003). Routine progesterone treatment of anestrous dairy cows has been questioned, however, particularly in New Zealand. McDougall \& Compton (2006) found that cows treated for anestrus calved early in the next calving season but failed to retain any advantage during the subsequent breeding period. Treating an anestrous cow and keeping her may only perpetuate the anestrous problem within a herd.

Until recently, behavioral anestrus (lack of estrus behavior for a cyclic cow) was viewed as only occurring at first postpartum ovulation (Inskeep 1995). Otherwise, cows classified as behaviorally anestrus were thought to have had estrus activity but this activity was not observed by humans (failed detection of estrus). Examination of data from electronic mount detectors demonstrated that high milk-producing cows had shorter estrous periods, fewer standing events, and less standing time when compared to low-milk producing cows (Lopez et al. 2004). The differences in estrous expression were linked to low blood estradiol concentrations in high-producing dairy cows. Low rates of estrous expression caused by low blood estradiol may explain the popularity of injectable formulations of estradiol for increasing blood estradiol, enhancing estrous expression and promoting ovulation in dairy cows (Moore \& Thatcher 2006). The use of estradiol for this purpose is only approved in some dairying countries (Lucy et al. 2004).

\section{Suboptimal and irregular estrous cyclicity}

Cows with estrous cycle abnormalities have poorer reproductive performance than their normalcycling herdmates (Hommeida et al. 2005; Mann et al. 2005; Petersson et al. 2006). The prevalence of estrous cycle abnormalities can approach 50\% in some herds. Estrous cycle abnormalities are classified into three primary types: 1) extended period of anovulatory anestrus, 2) temporary cessation of luteal phases, and 3) long luteal phases (greater than 20 days). Factors known to affect postpartum cows such as negative energy balance, periparturient disorders, and postpartum diseases are risk factors for abnormal estrous cycles (Opsomer et al. 2000). The incidence of twinning and cystic ovarian disease has also increased in modern dairy cattle because there are positive genetic correlations between these abnormalities and level of milk production (Vanholder et al. 2006; Wiltbank et al. 2006). Lucy (2003) proposed that a common physiological mechanism (low LH pulsatility, low blood growth factor concentrations, and enhanced steroid metabolism) may underlie the increased incidence of anovulatory anestrus, abnormal estrous cycles, and twinning. This common mechanism appears to be a consequence of the hormonal and metabolic state that supports a high level of milk production. Cystic ovarian disease apparently arises through a completely different physiological mechanism because cystic cows have high blood LH activity (Vanholder et al. 2006).

There is accumulating evidence that one component of infertility in dairy cows is caused by low blood progesterone concentrations after insemination (Stronge et al. 2005; McNeill et al. 2006a; Starbuck et al. 2006). A slow rise in progesterone delays embryonic development because early 
embryonic growth is partially dependent on progesterone perhaps acting at the level of the oviduct or endometrium (Green et al. 2005; Mann et al. 2006; McNeill et al. 2006b). Cows with low progesterone had equivalent blood LH concentrations and in vitro steriodogenic capacity when compared to normal cows (Robinson et al. 2006). Thus, the corpus luteum (Cl) may be normal but its capacity to elevate blood progesterone may be less in lactating cows. The relatively large body size of dairy cows may create a large tissue pool size and steroid metabolism may be greater (Wiltbank et al. 2006). The combined effects of pool size and turnover rate may lead to low blood progesterone. The same mechanism may lead to low blood estradiol in high-producing dairy cows (see above).

\section{Abnormal preimplantation embryo development}

The metabolic state of high-producing dairy cows may have a direct effect on the oocyte. Snijders et al. (2000) found that in vitro fertilized oocytes from dairy cows in low body condition had a lower cleavage rate and a lower developmental rate when compared with oocytes from dairy cows in better body condition. Oocyte quality could be improved, however, when low body condition heifers were fed at a high level (Adamiak et al. 2005). Sartori et al. (2002) flushed the reproductive tract of lactating cows and found fewer cleavage stage embryos when compared to similar flushes in nonlactating cows. Nonesterified fatty acids (NEFA) are released from adipose tissue in early lactation and their concentrations are increased in follicular fluid (approximately $40 \%$ of serum concentrations; Leroy et al. 2005). The increase in NEFA within follicular fluid may decrease the proliferation of granulosa cells (Vanholder et al. 2005) and may also affect the oocyte directly. Both Burkhart et al. (2005) (confinement system dairy cows) and McDougall et al. (2005a) (pasture system dairy cows) found that high NEFA concentrations were predictive of low fertility postpartum. The addition of NEFA to in vitro maturation medium decreased maturation rate, fertilization rate, cleavage rate, and blastocyst yield for in vitro cultured embryos (Leroy et al. 2005). Collectively the data suggest that early embryonic development is compromised by lactation perhaps through elevated NEFA that enters the follicular fluid and damages the oocyte. Fewer embryos reach the cleavage stage because oocyte quality is low.

If the primary mechanism leading to infertility involves the oocyte or early embryo then embryo transfer should improve conception rates in postpartum dairy cows. Heat stress is known to negatively affect the early embryo, for example, and heat-stressed dairy cows subjected to embryo transfer have a higher conception rate than those inseminated by conventional AI (Hansen et al. 2001). Embryo transfer pregnancy rates for dairy cows were increased by greater than $10 \%$ over control dairy cows inseminated at estrus in two studies (Demetrio et al. 2006; Vasconcelos et al. 2006) but a third study failed to demonstrate an effect (Sartori et al. 2006). Thus, there is some evidence to support the concept that fertility can be recovered in dairy cows by circumventing the period of oocyte and early embryonic development. The condition of the recipient cow, however, is one factor that can potentially affect the outcome because Mapletoft et al. (1986) reported that body condition has a large effect on embryo transfer success (higher body condition score cows have higher pregnancy rates after transfer). Thus uterine environment as affected by body condition plays some role in the fertility of dairy cows.

\section{Uterine/placental incompetence}

The uterus of postpartum cows may appear grossly normal but nonetheless fail to support preg- 
nancy (Gilbert et al. 2005). Failure to support the pregnancy typically manifests itself during the early embryonic period (Santos et al. 2004). Embryonic loss was traditionally viewed as occurring during the period of maternal recognition of pregnancy (days 17 to 21 of pregnancy; Thatcher et al. 2001). Losses during this early period extended the estrous cycle in inseminated cows but were manageable because cows returned to estrus during the fourth week after Al. Ultrasonography revolutionized pregnancy detection in beef and dairy cattle because pregnancy could be detected as early as day 25 after insemination (about 1 to 2 weeks earlier than manual palpation; Miyamoto et al. 2006). Examination of ultrasound data revealed that appreciable numbers of embryos died after the initial pregnancy examination (done between days 25 and 28 after Al; Santos et al. 2004). This later period of embryonic loss leads to the "phantom cow syndrome" where inseminated cows fail to return to estrus and are difficult to resynchronize using conventional methods (Cavalieri et al. 2005). A likely period for embryonic death may be during placentation (fourth to sixth week of pregnancy) because placentation involves intricate communication between maternal and fetal tissues (King et al. 1982). Whether or not the incidence of embryonic loss is greater now than in the past is debated because the capacity to routinely detect early pregnancy in cattle evolved with the use of ultrasound in cattle (after 1984; Pierson \& Ginther 1984).

Embryonic loss in modern dairy cattle probably arises from predisposing factors that are common in dairy systems. Dairymen may inseminate cows early postpartum because they are fearful that they will not observe a subsequent estrus. Cows inseminated early postpartum are more likely to have embryonic loss whether they are in confinement or pasture-based systems (McDougall et al. 2005b; Meyer et al. 2006). Disease is a predisposing factor as well. Gilbert et al. (2005) found that $53 \%$ of cows had evidence of uterine inflammation (endometritis) at 40 to 60 days postpartum. Cows with endometritis had lower first service conception rates, required more services per conception, and had pregnancy rates at 300 days postpartum that were 26 percentage points lower than cows with a healthy endometrium. Similar effects were observed in pasture-based dairy cows (McDougall et al. 2006). A link between mastitis and early embryonic loss has also been established (Chebel et al. 2004). The mastitic mammary gland activates immune cells whose inflammatory cytokines adversely affect the ovary and uterus (Hansen et al. 2004).

The final predisposing factor for embryonic loss arises from the relatively low body condition of postpartum dairy cows. Several studies have tied high postpartum milk production or low postpartum body condition to early embryonic loss (Grimard et al. 2006; Vasconcelos et al. 2006). Silke et al. (2002) found that embryonic loss after day 28 of pregnancy was highest in cows losing the greatest amount of body condition.

\section{Short-term strategies for increasing fertility in dairy cows}

There are both short and long-term solutions for solving dairy infertility. Some short-term solutions have no conceivable drawbacks and should be enacted immediately. Other short-term solutions can be implemented immediately but they are not necessarily sustainable solutions for dairy cow infertility because they may be too expensive, too difficult to enact, or unacceptable in the eye of the public or the dairy farmer. Individual solutions have more or less merit depending on the laws governing dairy production and the economics of the dairy production system.

\section{Using high fertility sires}

The importance of semen handling and $\mathrm{Al}$ technique to successful reproduction cannot be understated. Assuming that semen is handled properly and placed appropriately within the 
female reproductive tract then the next obvious step is to use highly fertile dairy sires. Dairy sire fertility is calculated and published in the United States by the Animal Improvement Programs Laboratory (AIPL; Beltsville, Maryland, USA) as Estimated Relative Conception Rate (ERCR). Dairy sires have inherent differences in fertility that are related to capacitation time and sperm survival in the female reproductive tract (Saacke et al. 2000). The ERCR is the estimated deviation from herd conception rate that can be expected with the use of a specific sire (i.e., +4 is four percentage points above herd average, etc.). Given inherent variation in reproductive data, ERCR should only be used for sires with a large number of services. Cornwell et al. (2006) used high versus low fertility sires in a timed Al program and demonstrated a tendency for an increase in conception rate when high fertility sires were used ( 6 percentage point increase; $P=0.12$ ). There is little difference in Net Merit (NM\$) for sires that are stratified across a wide range of ERCR (Fig. 3). Thus, it is possible to achieve genetic gain while using sires with superior fertility in an Al system.

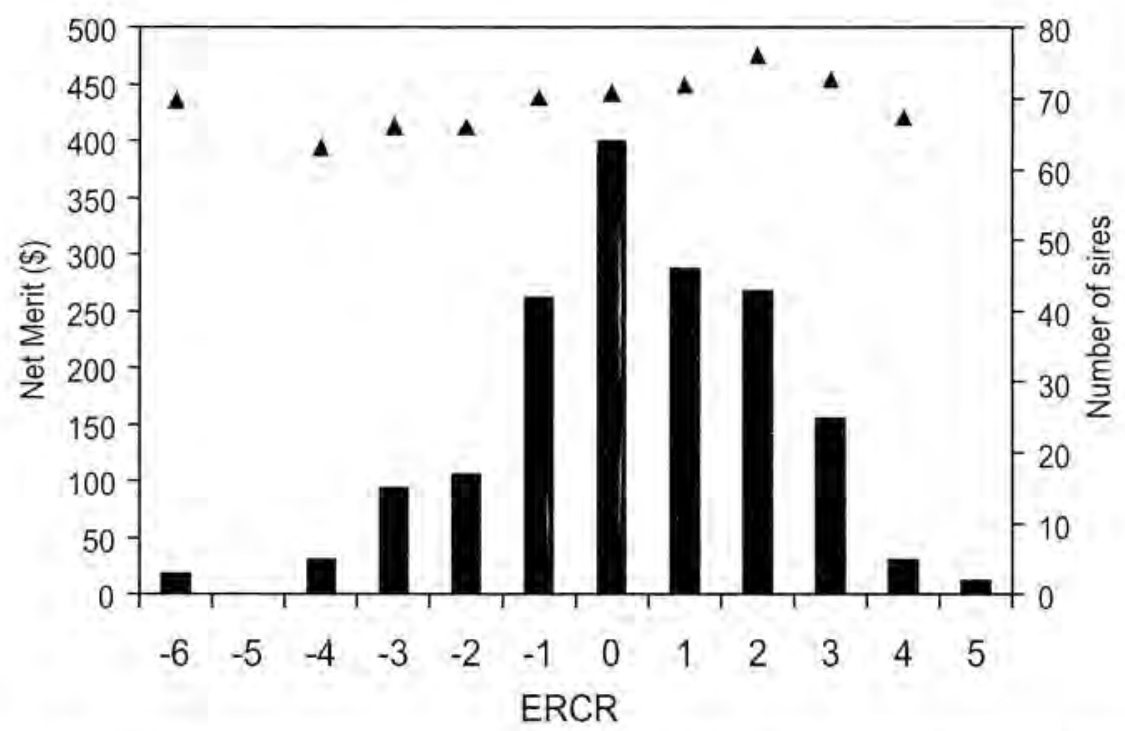

Fig. 3. Average Net Merit (triangle) and number of active artificial insemination sires (bar) for different estimated relative conception rates (ERCR; statistics are for the May 2006 evaluation; Animal Improyement Programs Laboratory; Beltsville, Maryland, USA).

Intensive reproductive management programs (synchronization and resynchronization)

An immediate solution to combat infertility in dairy herds involves intensive management of the estrous cycle and ovulation (estrous synchronization and timed Al). Numerous review articles have been published on the methods that can be used to do this (Diskin et al, 2002; Rhodes et al. 2003; Lucy et al. 2004; Moore \& Thatcher 2006). Most approaches employ a method for controlling follicular wave development, promoting ovulation in anestrous cows, regressing the corpus luteum in cyclic cows, and synchronizing estrus and (or) ovulation at the end of treatment. In many dairy herds, cows are inseminated after spontaneous estrus for a predetermined period and then cows that have not been inseminated are managed intensively (timed Al). More intensive approaches to reproductive management involve programmed breeding for all inseminations without any type of estrous detection. 
There is variation between countries in availability and regulatory requirements for hormonal treatments used in estrous synchronization. For example, estradiol benzoate is actively used in New Zealand and Australia but is not registered in the European Union or the United States. The only approved estradiol for United States dairy cows (estradiol cypionate) was voluntarily removed from the market by its manufacturer (Pfizer Animal Health). New Zealand and Australia have had intravaginal progesterone releasing devices for use in lactating cows for over 15 years but the devices were only recently approved for United States dairy cattle. In the United Kingdom, PGF . $_{2 \alpha}$ must be administered by a veterinary surgeon and this requirement makes its routine use too expensive. There is global public concern about the blanket application of hormones to food-producing animals.

Timed Al is popular in large confinement dairies because the benefits of a timed Al system increase under conditions of poor estrous detection rate (Lucy et al. 2004). A popular method for timed Al practiced in North American herds is "Ovsynch" (GnRH; wait seven days; $\mathrm{PGF}_{2 \alpha^{\prime}}$ wait two days; GnRH; Lucy et al. 2004). Cows are either inseminated at the same time as the last GnRH (Cosynch) or 16 to 24 hours after the final GnRH treatment (Ovsynch). In a meta analysis of 53 research papers, Rabiee et al. (2005) concluded that conception and pregnancy rates after synchronization programs with estrous detection and after Ovsynch were similar. The Ovsynch program has distinct advantages over estrous synchronization procedures because estrous detection is not required and every cow is inseminated at the end of treatment $(100 \%$ submission rate). A progesterone-containing device (CIDR) can be added into the Ovsynch program (inserted after the first $\mathrm{GnRH}$ and removed after the first $\mathrm{PGF}_{2 \alpha}$ ) and this will improve conception rate in some herds (Stevenson et al. 2006). Follicular wave synchronization followed by timed $\mathrm{Al}$ is more efficacious when cows are between days 5 and 12 of the estrous cycle. Thus, a pre-synchronization strategy can be employed in which cows are treated with a series of PGF ${ }_{2 \alpha}$ injections before the Ovsynch protocol (Thatcher et al. 2002). Pre-synchronization improves conception rate after Ovsynch by 5 to $10 \%$.

Cows that are not pregnant after first insemination can be resynchronized for second Al. Progesterone-alone can be used for the purpose of grouping estruses in cows that are not pregnant after first insemination (McDougall 2003). For resynchronization timed Al, the first GnRH injection of Ovsynch can be given to all cows approximately one week before pregnancy diagnosis (Chebel et al. 2003). Cows that are subsequently diagnosed non-pregnant can be injected with $\mathrm{PGF}_{2 \alpha}$ and 48 hours later injected with $\mathrm{GnRH}$ before timed $\mathrm{Al}$. An alternative method is to simply start cows back on Ovsynch once they are diagnosed non-pregnant (Sterry et al. 2006).

An obvious detraction for pre-synchronization timed Al methods (for example, PresynchOvsynch) is that a series of five injections is required and the injections occur over a 45-day period. If a post-insemination treatment is applied (see below) and cows are placed back on a re-synchronization program then a cow that is not pregnant to first insemination (the mostprobable outcome) will receive nine injections before her second insemination and a total of ten injections if she is again treated post-insemination (Fig. 4). Assuming a 35\% timed AI conception rate, a group of 100 cows would receive 860 injections and achieve 58 pregnancies after two inseminations (about 15 injections per pregnancy). Many managers of large herds feel that scheduling reproductive treatments and inseminations is simpler and more effective than multiple daily sessions of estrous detection. Their approach has merit, given the difficult nature of estrous detection in large herds (Lucy 2001). The example stated above assumes no estrous detection. In reality, North American herds that use Presynch-Ovsynch and re-synchronization typically inseminate any cow that is seen in estrus (essentially terminating the program until pregnancy examination; Stevenson \& Phatak 2005). 

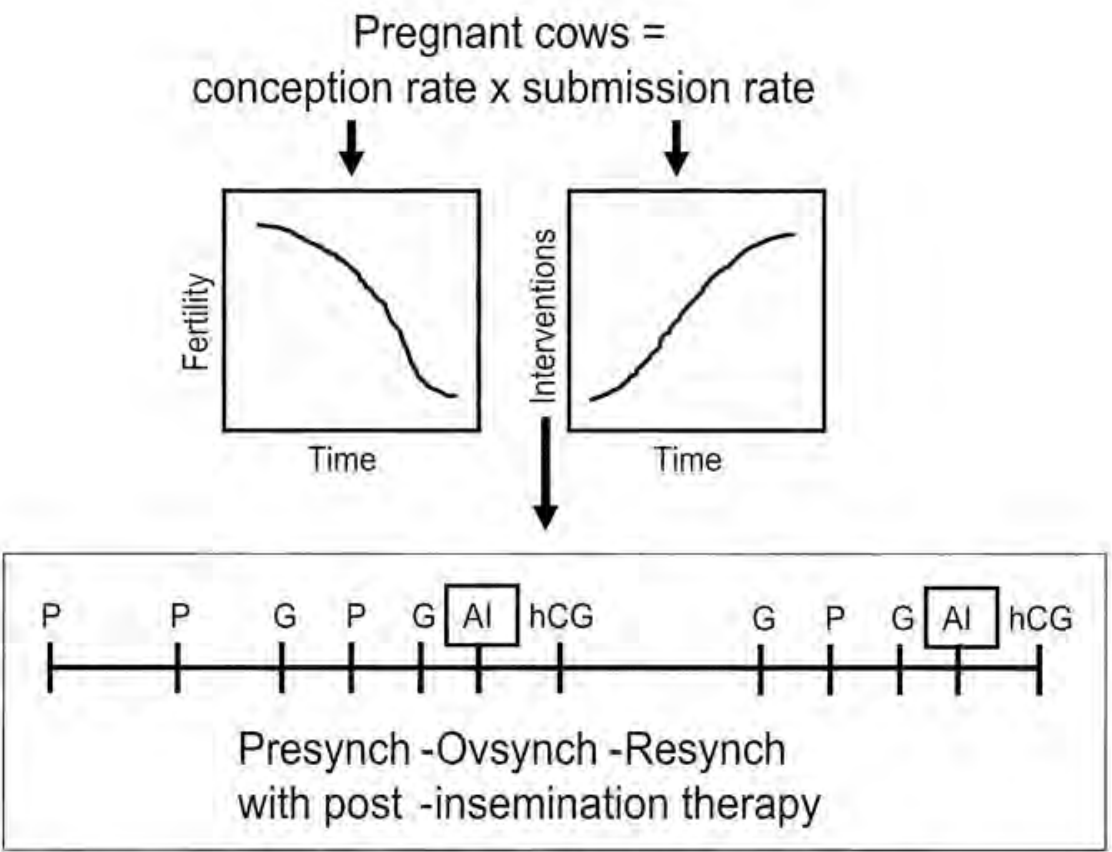

Fig. 4. The number of pregnant cows is a function of conception rate and submission rate. As conception rates (fertility) have declined over time, farmers have increased submission rates by intensive reproductive intervention such as timed Al. An example of a timed Al program is the Presynch-Ovsynch-Resynch program that includes a post-insemination treatment (hCG) to increase fertility. In this system a cow receives six injections before or shortly after first $\mathrm{Al}\left(\mathrm{P}-\mathrm{PGF}_{2 \alpha^{\prime}} \mathrm{G}-\mathrm{G} n \mathrm{RH}\right)$ ). If she is not pregnant for first $\mathrm{Al}$ then she will receive four additional injections for second $\mathrm{Al}$. The success rate of the program is about $35 \%$ for first $\mathrm{Al}$ and somewhat less for second $\mathrm{Al}$ so that only 50 to $60 \%$ of cows are pregnant after two Al. Repeated hormonal injections that return relatively low pregnancy rates may not be a sustainable option for maintaining fertility on dairy farms.

An average of fifteen injections per dairy cow pregnancy is a troublesome number. A question raised by Macmillan et al. (2003), and restated here, concerns the effectiveness of our current programs for estrous synchronization. When is the point of diminishing returns reached? Estrous synchronization and timed Al programs have become the primary method to combat the declining trend in fertility within North American dairy herds. What was once a method to control the estrous cycle and to group cows in estrus is now the only possible means of achieving acceptable submission rates in large confinement dairies. The situation for dairy cows contrasts greatly from that of beef cows where timed Al programs with fewer injections can achieve conception rates above $60 \%$ (Schafer et al. 2005). Improving the underlying fertility of dairy cattle (see below) may increase pregnancy rates for timed $\mathrm{Al}$ in dairy cows and simplify timed Al programs because fewer injections will be needed.

\section{Treating cows after insemination}

Treatments can be applied to dairy cows after insemination in an effort to improve fertility. The reader is referred to several recent reviews of the subject (Macmillan et al. 2003; Thatcher et 
al. 2006). There are three primary strategies. The first strategy addresses low progesterone during the first week after breeding. An injection of GnRH or hCG given between days 5 to 8 of the estrous cycle will cause the ovulation of accessory $\mathrm{CL}$ in some cows and may also improve $\mathrm{CL}$ function (hCG through its LH-like activity). A progesterone-containing device may also be inserted during this period and left in place for approximately one week. The aforementioned treatments may increase progesterone in blood and there is a positive correlation between blood progesterone and fertility (see above). The second strategy involves GnRH treatment later in the estrous cycle. Turning over or ovulating the dominant follicle decreases estradiol and blocks the luteolytic mechanism. Delaying luteolysis will increase the amount of time that the embryo has to signal the mother. In practice, the two strategies described above suffer from herd by treatment interactions where there is a positive response in some herds but not others. The underlying cause of the herd effect is unknown. The treatments may be most-successful when they are applied to lactating cows in low body condition (i.e., targeting cows with the greatest risk of infertility; Thatcher et al. 2006). It may be necessary to periodically retest these treatments as dairy cattle continue to evolve in the future. What was not effective in the past may be effective in the future because dairy cows have changed genetically.

The third strategy is the administration of recombinant bovine somatotropin (rbST) around the time of insemination. Recombinant bST is inexpensive in the United States and is approved for the purpose of increasing milk production. An injection of rbST increases blood IGF-I concentrations. Embryonic and uterine tissues typically respond positively to IGF-I (Thatcher et al. 2006). Cows with elevated blood IGF-1 are more fertile. For example, Taylor et al. (2004) reported that dairy cows with blood IGF-I concentrations greater than $50 \mathrm{ng} / \mathrm{ml}$ had a five-fold increase in pregnancy rate. Application of rbST at AI has been shown to be efficacious for increasing pregnancy rate for cows inseminated by timed $\mathrm{Al}$ and at estrus (Thatcher et al. 2006).

\section{Feeding diets that are designed to improve fertility}

Developing diets that increase the fertility of dairy cows has always been an attractive option to scientists and farmers. In North American confinement-style herds and in pasture-based systems, farmers have some flexibility in terms of the diets and supplements that they feed. The diet is mixed and fed along a fence-line or in the milking parlor so there is no need to handle individual cows when feeding a specially-designed diet.

Negative energy balance, weight loss, and decreased body condition score occur during early lactation when nutrient requirements for maintenance and lactation exceed the ability of the cow to consume energy in the feed. Cows in negative energy balance have lower blood concentrations of insulin and IGF-I (Lucy 2004). Low blood IGF-I causes reduced negative feedback on growth hormone $(\mathrm{GH})$ and an increase in blood $\mathrm{GH}$ concentrations (Lucy 2000). Greater blood GH increases liver gluconeogenesis and promotes lipolysis (NEFA release) from adipose tissue. High blood $\mathrm{GH}$ and NEFA concentrations antagonize insulin action and create a state of insulin resistance in postpartum cows. The insulin resistance blunts glucose utilization by non-mammary tissues and conserves glucose for milk synthesis. The cycle described above (low IGF-1, high GH, low glucose, low insulin, and insulin resistance) is gradually reversed during the first 4 to 8 weeks of lactation.

The aforementioned endocrine hormones (insulin and IGF-1) that are metabolically controlled can influence GnRH and LH secretion (Lucy 2003). Insulin and IGF-I can also act directly on the ovary to increase the sensitivity of the ovary to $\mathrm{LH}$ and FSH. Postpartum dairy cows are thought to be less sensitive to $\mathrm{LH}$ and FSH because their insulin and IGF-I concentrations are low. Although typically thought to affect ovarian function, the insulin/IGF system is clearly resident within the 
uterus and embryo (Watson et al. 1999). Therefore, insulin and IGF-I may be tied to an effect of body condition on the uterus and embryo.

Roche et al. (2006) found that cows with North American pedigrees in a New Zealand system increased milk production (and not body condition) when fed additional energy. Likewise, North American dairy cows consume feed ad libitum but nevertheless use all available nutrients for milk production at the expense of body condition (Bauman \& Currie 1980). Nutrient partitioning prevents the transition out of the catabolic state because all of the available glucose is consumed, primarily for milk synthesis (Lucy 2004). Feeding more energy may not solve reproductive problems in dairy cows selected for milk production because the cows will partition additional nutrients toward milk production and not toward adipose or reproductive tissues. The metabolic state of low insulin, low IGF-I and elevated GH is maintained despite the higher level of feeding.

Perhaps a more realistic approach to feeding dairy cows for fertility is to provide specific nutrients that are designed to impinge upon the endocrine system of the cow (nutraceutical-type approach). Examples of this include feeding hyperinsulinemic diets (Gong et al. 2002) and supplementing with propylene glycol (Miyoshi et al. 2001; Butler et al. 2006). In each case, blood glucose and insulin concentrations are strategically increased and fertility may be improved because the cow is "tricked" into thinking that she is anabolic. It is also possible to tailor the fatty acid composition of the diet. Feeding polyunsaturated fatty acids may improve reproduction in dairy cows because the $\mathrm{PGF}_{2 \alpha}$-synthesizing luteolytic mechanism is attenuated (Mattos et al. 2000).

\section{Long-term strategies for increasing fertility in dairy cows}

The problems facing reproduction in dairy cattle are not simple. A reversal in the current trends can be achieved only through a variety of approaches. The short-term solutions provided above should be pursued. In the long-term, the current trend in inbreeding needs to be attenuated and cows should be actively selected for improved reproductive efficiency.

\section{Inbreeding in dairy cows}

Inbreeding in dairy cattle breeds has increased dramatically since 1980 and may play a role in reproductive decline (Funk 2006). Present levels of inbreeding for United States cows are greater than $5 \%$ and continue to increase in most breeds. Inbreeding negatively affects reproductive and longevity traits in dairy cows (Sewalem et al. 2006; VanRaden \& Miller 2006). One way to correct inbreeding is through crossbreeding. Dairy farmers in New Zealand routinely crossbreed their cows; so much so that crossbred cows may soon outnumber purebred Holstein-Friesian (Harris 2005). Crossbreeding in the United States is practiced by a small number of farmers. The major Jimitation is that the Holstein breed is superior to all others in terms of milk production. Thus, although there is heterosis for milk production, the crossbred cow produces less milk than the Holstein (Heins et al. 2006a). Holstein-Jersey crossbred cows had better fertility than Holstein cows when studied within a university research herd (Heins et al. 2006b). In the long-term, it may be necessary to develop multiple lines of dairy cattle with equivalent capacity for milk production so that crossbreeding can be used to maintain genetic diversity and capitalize on heterosis.

Improving dairy cattle genetics for reproduction traits

Genetic selection programs for dairy cattle have capitalized on partitioning nutrients away from adipose tissue. This was not a preplanned strategy of genetic selection (i.e., cows were not pur- 
posely selected for low body condition in early lactation) but instead was a consequence of the genetic selection for milk production (the highest producing cows had genetics that supported the low body condition phenotype). The homeorhetic mechanisms that supported the low body condition phenotype were viewed as positive and highly desirable, particularly in the North American system. Low body condition during lactation, however, antagonizes reproduction (Pryce \& Harris 2006). Dairy fertility has economic value but how much value does it have relative to the value of milk? Reproduction will not improve if it is undervalued relative to other traits in the selection index but reproduction should not be over-valued relative to other traits simply to correct a perceived problem.

There has clearly been a change in the way we select dairy cattle. A historical examination of the primary selection indices in the United States clearly shows a shift toward longevity and functional traits since the mid-1990's (Fig. 5). The worldwide decline in dairy fertility is being addressed by including fertility traits in selection indices (Lucy 2005). The Scandinavians were the first to do this, and other countries followed in the past decade (Lindhe \& Philipsson 1998). It is impossible to capture each of the individual fertility components listed above. Instead, time to pregnancy, i.e. the most meaningful outcome, is measured. The United States has adopted daughter pregnancy rate (DPR) for fertility weightings (VanRaden et al. 2004). The DPR is based on days open, i.e. the number of days from calving to conception. A $1 \%$ increase in DPR is equivalent to a 4-day reduction in days open. In untreated cattle, the DPR captures cyclicity, expression of estrus and fertility (conception rate), in a single measure. The DPR breeding value for North American Holstein and Jersey cows has declined since 1957 but appears to have stabilized (Lucy 2005). The correlation between DPR and NM\$ for United States dairy sires is nearly zero; meaning that sires at the top of the selection index are neutral for DPR (Fig. 6). There is clearly a negative correlation between DPR and milk traits such as protein yield. Thus, the selection index (that theoretically reflects profitability) may be the best method for selecting future sires because balanced selection does not place reproductive traits at a disadvantage.

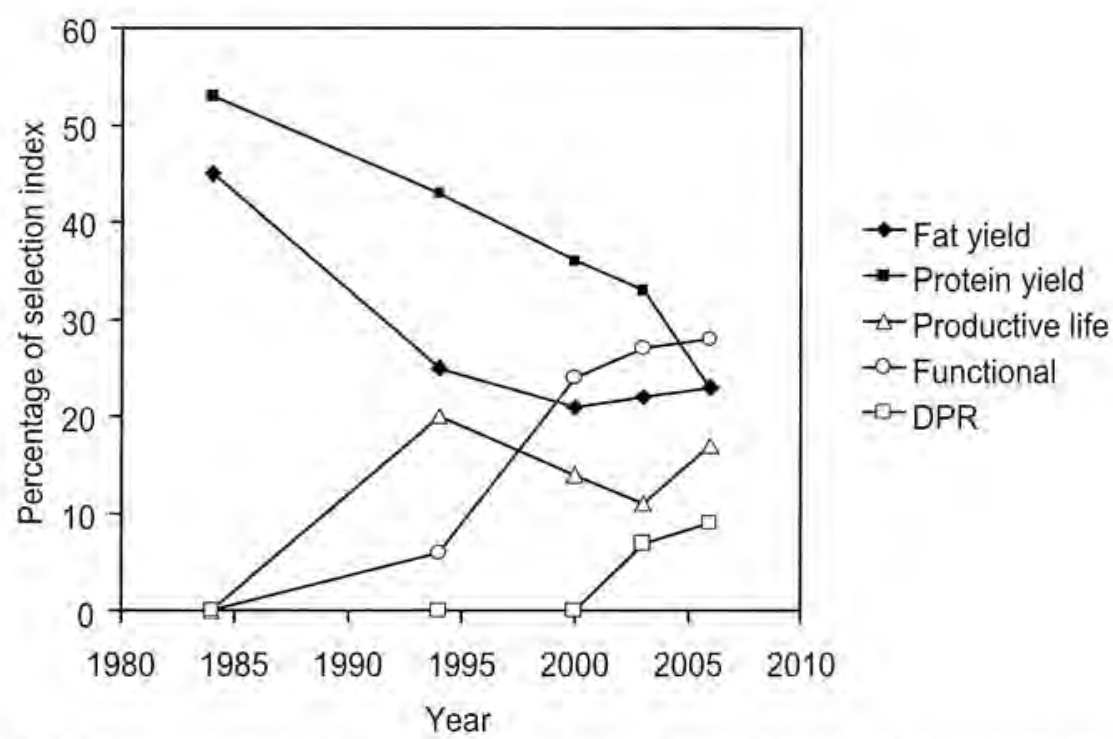

Fig. 5. Relative emphasis of different traits in United States dairy selection indexes (Animal Improvement Programs Laboratory, Beltsville, Maryland, USA). Since 1994, the weightings for fat and protein yield have decreased whereas the weightings for productive life, functional traits (somatic cell score, udder, feet and legs, etc.) and daughter pregnancy rate (DPR) have increased. 

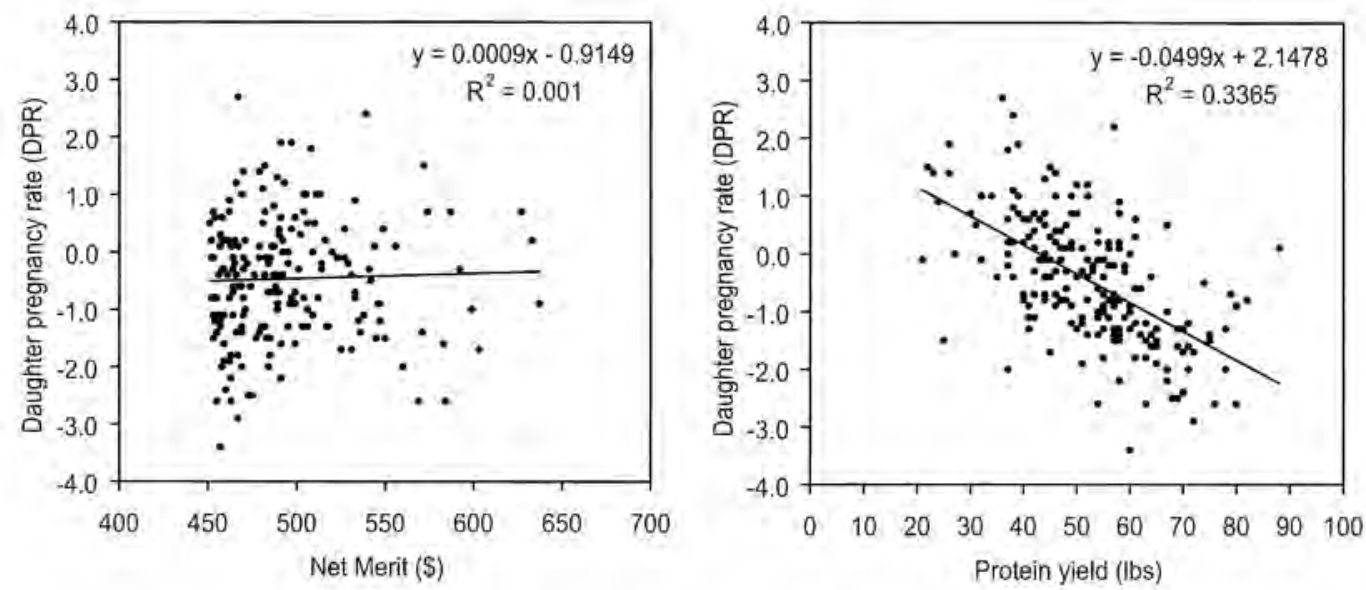

Fig. 6. Regression of daughter pregnancy rate (DPR) on Net Merit (left panel) and protein yield (right panel) for Holstein sires (Animal Improvement Programs Laboratory, Beltsville, Maryland, USA). There is no relationship between DPR and Net Mer it. This indicates that DPR does not change across sire rankings within the Net Merit index. Using a single fr ait such as protein yield, however, clearly leads to lower DPR when the top sires are selected.

Most of the available literature suggests that dairy cattle have a genetically-determined set point for body condition during lactation (Stockdale 2001). Once dairy cows begin lactation, they will migrate toward their body condition set point through the coordinated depletion of adipose tissue. The magnitude of adipose tissue loss does not depend on nutrient demands per se but instead depends on the available adipose tissue mass and the genetically-determined set point for the individual cow. There is wide-spread consensus that the genetically-determined set point for body condition during lactation affects the reproductive performance of dairy cows (Berry et al. 2003; Pryce \& Harris 2006). The lower body condition of modern dairy cows reflects the genetic predisposition to direct nutrients away from body fat during lactation (homeorhetic mechanism that supports milk production).

Since there are strong positive genetic trends between body condition and reproductive performance then selection programs based on postpartum body condition score should alleviate some reproductive loss (Pryce et al. 2002). Milk that is made in early lactation could be made in later lactation if selection indices emphasized a persistent lactation instead of a high peak milk yield. This change in emphasis would improve the body condition of cows during the breeding period and could improve reproductive success simply because cows are in better body condition when they are inseminated. There has been little attention paid to residual feed intake (RFI; the difference between an animal's actual feed intake and its expected feed intake based on nutrient requirements; Crews 2005). Such an energetic efficiency measure may have utility particularly when feed has limited availability (pasture systems) or represents a high percentage of costs (confinement systems). If RFI were applied to lactating dairy cows then the RFI calculation would have to account for the milk energy gained from adipose tissue mobilization. Otherwise, cows that lose excessive adipose tissue would have a low RFI but also a low body condition.

Reproductive traits have low heritabilities but the coefficient of variation for reproductive traits is large. Therefore, genetic selection for good fertility is possible in dairy cattle (Weigel 
\& Rekaya 2000). The current situation with dairy reproduction genetics is not a blind alley. The problem can be corrected without retrenching in terms of milk production. It is, of course, scientifically appealing to predict how dairy cows will change if they are simultaneously selected for both milk production and reproduction traits. The above discussion implies that high fertility cows will have lactation curves that are flatter so that the cow maintains better body condition throughout lactation. An alternative and equally reasonable possibility is that highproducing cows with good fertility will have reproductive systems that function efficiently under conditions of high milk production. There is no biological reason that this cannot occur in as much as some species reproduce naturally under extreme metabolic conditions. For example, Bauman \& Currie (1980) described the work of Miescher who in 1880 noted that the reproductive organs of salmon developed extensively during their migration up the Rhine River when $55 \%$ of muscle mass was lost. Selection for milk production was done without any preconceived notion as to how it would change the cow. Likewise, genetic selection for reproductive traits should be practiced in the same manner with the sole objective of achieving better fertility through a balanced approach. Simply maintaining current fertility levels may be unacceptable because pregnancy rates are low and the level of reproductive intervention is high on modern dairy farms.

\section{Conclusions}

Single-pronged approaches will probably not reverse the current decline in dairy fertility because the underlying causes are multi-faceted and appear to affect the reproductive process at nearly every level. In the short-term, aggressive reproductive management (treatment of anestrus, use of high fertility sires, estrous synchronization and re-synchronization, post-insemination treatments, etc.) should maintain current reproductive rates. Routine treatment of food animals with hormones will likely become a concern to the public so these approaches may become unavailable to farmers. In the United States, for example, we have recently witnessed the removal of a popular estrous synchronization product from the market (estradiol cypionate). Formulating diets to improve reproduction is perhaps a more sustainable option because farmers are used to changing diets to suit their management objectives. A long-term solution is to improve the reproductive genetics of the dairy cow. This includes addressing the potential impact of inbreeding and also reversing the genetic trends that underlie the current pattern of reproductive decline. Although progress toward greater milk production may be less, the cow will be healthier and easier to manage because she will become pregnant more easily.

\section{References}

Andersen-Ranberg IM, Klemetsdal G, Heringstad B \& Steine T 2005 Heritabilities, genetic correlations, and genetic change for female fertility and protein yield in Norwegian Dairy Cattle. Journal of Dairy Science $\mathbf{8 8}$ 348-355.

Adamiak SJ, Mackie K, Watt RG, Webb R \& Sinclair KD 2005 Impact of nutrition on oocyte quality: cumulative effects of body composition and diet leading to hyperinsulinemia in cattle. Biology of Reproduction 73 918-926.

Bauman DE \& Currie WB 1980 Partitioning of nutrients during pregnancy and lactation: a review of mechanisms involving homeoslasis and homeorhesis. Journal of Dairy Science 63 1514-1529.
Beam SW \& Butler WR 1999 Effects of energy balance on follicular development and first ovulation in postpartum dairy cows. Journal of Reproduction and Fertility Supplement 54 411-424.

Berry DP, Buckley F, Dillon P, Evans RD, Rath M \& Veerkamp RF 2003 Genetic relafionships among body condition score, body weight, milk yield, and fertility in dairy cows. Journal of Dairy Science $\mathbf{8 6}$ 2193-204.

Burkhart M, Youngquist R, Spain J, Sampson J, Bader J, Vogel R, Lamberson W \& Garverick HA 2005 NEFA and glucose levels in serum of periparturient dairy cows are indicative of pregnancy success at first service. Journal of Animal Science 83 (Supple- 
ment 1) 299 (abstract).

Butler ST, Pelton SH \& Butler WR 2006 Energy balance, metabolic status, and the first postpartum ovarian follicle wave in cows administered propylene glycol. Journal of Dairy Science 89 2938-2951.

Cavalieri I, Rabiee AR, Hepworth G \& Macmillan KL $2005 \mathrm{Effecl}$ of artificial insemination on submission rates of lactating dairy cows synchronised and resynchronised with intravaginal progesterone releasing devices and oestradiol benzoate. Animal Reproduction Science 90 39-55.

Chebel RC, Santos JE, Cerri RL, Galvao KN, Juchem SO \& Thatcher WW 2003 Effecl of resynchronization with $\mathrm{GnRH}$ on day 21 after artificial insemination on pregnancy rate and pregnancy loss in lactating dairy cows. Theriogenology 60 1389-1399.

Chebel RC, Santos JE, Reynolds JP, Cerri RL, Juchem SO \& Overton M 2004 Factors affecting conception rale after artificial insemination and pregnancy loss in lactating dairy cows. Animal Reproduction Science 84 239-25.

Cornwell JM, McGilliard ML, Kasimanickam R \& Nebel RL 2006 Effecl of sire fertility and liming of artificial insemination in a Presynch + Ovsynch protocol on first-service pregnancy rates. Journal of Dairy $5 \mathrm{ci-}$ ence 89 2473-2478.

Crews DH Jr 2005 Genetics of efficient feed utilization and national cattle evaluation: a review. Genetics and Molecular Research 4 152-165.

Demetrio DGB, Santos RM, Demetrio CGB, Rodrigues CA, \& Vasconcelos JLM 2006 Factors affecting conception of AI or ET in lactating cows. Journal of Animal Science 84 (Supplement 1) 207-208 (abstract).

Diskin MG, Austin EJ \& Roche JF 2002 Exogenous hormonal manipulation of ovarian activity in cattle. Domestic Animal Endocrinology 23 211-228.

Funk DA 2006 Major advances in globalization and consolidation of the artificial insemination industry. Journal of Dairy Science 89 1362-1368.

Gilbert RO, Shin ST, Guard CL, Erb HN \& Frajblat M 2005 Prevalence of endometritis and its effects on reproductive performance of dairy cows. Theriogenology 64 1879-1888.

Gong JG 2002 Influence of metabolic hormones and nutrition on ovarian follicle development in cattle: practical implications. Domestic Animal Endocrinology $23229-241$.

Gong JG, Lee WJ, Garnsworthy PC \& Webb R 2002 Effect of dietary-induced increases in circulating insulin concentrations during the early postpartum period on reproductive function in dairy cows. Reproduction 123 419-427.

Green MP, Hunter MG \& Mann GE 2005 Relationships between maternal hormone secretion and embryo development on day 5 of pregnancy in dairy cows. Animal Reproduction Science 88 179-189.

Gumen A, Guenther JN \& Wiltbank MC 2003 Follicular size and response to Ovsynch versus detection of estrus in anovular and ovular lactating dairy cows. Journal of Dairy Science 86 3184-3194.

Grimard B, Freret S, Chevallier A, Pinto A, Ponsart C
\& Humblot P 2006 Genetic and environmental factors influencing first service conception rate and late embryonic/foetal mortality in low fertility dairy herds. Animal Reproduction Science 91 31-44.

Hansen LB 2000 Consequences of selection for milk yield from a geneticist's viewpoint. Journal of Dairy Science 83 1145-1150.

Hansen PI, Drost M, Rivera RM, Paula-Lopes FF, alKatanani YM, Krininger CE \& Chase CC Jr. 2001 Adverse impact of heat stress on embryo production: causes and strategies for miligation. Theriogenology 55 91-103.

Hansen PJ, Soto P \& Natzke RP 2004 Mastitis and fertility in cattle - possible involvement of inflammation or immune activation in embryonic mortality. American Journal of Reproductive Immunology 51 294-301.

Harris BL 2005 Breeding dairy cows for the future of New Zealand. New Zealand Veterinary Journal 53 384-389.

Harris BL \& Kolver ES 2001 Review of Holsteinization on intensive pastoral dairy farming in New Zealand. lournal of Dairy Science 84 E56-E61.

Heins BJ, Hansen LB \& Seykora AJ 2006a Production of pure Holsteins versus crossbreds of Holstein with Normande, Montbeliarde, and Scandinavian Red. Journal of Dairy Science 89 2799-2804.

Heins BJ, Hansen LB, Seykora AJ, Hazel AR, Linn IG, Johnson DG, \& Hansen WP 2006b Crossbreds of Jersey/Holstein compared to pure Holsteins for production, calving difficulty, stillbirths, and ferlility. lournal of Dairy Science 89 (Supplement 1) 245 246 (abstract).

Hommeida A, Nakao T \& Kubota H 2005 Onsel and duration of luteal activity poslparlum and their effect on first insemination conception rate in lactating dairy cows. Journal of Veterinary Medical Science 67 $1031-1035$.

Inskeep EK 1995 Factors that affect fertility during oestrous cycles with short or normal luteal phases in postpartum cows. Journal of Reproduction and Fertility Supplement 49 493-503.

King GJ, Atkinson BA \& Robertson HA 1982 Implantation and early placentation in domestic ungulates. Journal of Reproduction and Fertility Supplement 31 17-30.

Kuhn M \& Hutchison J 2005 Factors affecting heifer fertility in US Holsteins. Joumal of Dairy Science 88 (Supplement 1) 11 (abstract).

Leroy IL, Vanholder T, Mateusen B, Christophe A, Opsomer G, de Kruif A, Genicot G \& Van Soom A 2005 Non-esterified fatty acids in follicular lluid of dairy cows and their effect on developmental capacity of bovine oocytes in vitro. Reproduction $\mathbf{1 3 0}$ 485-495.

Lindhe B \& Philipsson I 1998 Conventional breeding programmes and genetic resistance to animal diseases. Reviews in Science and Technology 17291 301.

Lopez H, Satter LD \& Wiltbank MC 2004 Relationship between level of milk production and estrous be- 
havior of lactating dairy cows. Animal Reproduction Science 81 209-223.

Lucy MC 2000 Regulation of ovarian follicular growth by somatotropin and insulin-like growth factors in cattle. Journal of Dairy Science $\mathbf{8 3}$ 1635-1647.

Lucy MC 2001 Reproductive loss in high-producing dairy cattle: Where will it end? lournal of Dairy Science $\mathbf{8 4}$ 1277-1293.

Lucy MC, Billings HJ, Butler WR, Ehnis LR, Fields MJ, Kesler DJ, Kinder JE, Mattos RC, Short RE, Thatcher WW, Wetlemann RP, Yelich JV \& Hafs HD 2001 Efficacy of an intravaginal progesterone insert and an injection of PGF2a for synchronizing estrus and shortening the interval to pregnancy in postpartum beef cows, peripubertal beef heifers, and dairy heifers. Journal of Animal 5cience $79982-995$.

Lucy MC 2003 Mechanisms linking nutrition and reproduction in poslpartum cows. Reproduction Supplement 61 475-427.

Lucy MC 2004 Mechanisms linking the somatotropic axis with insulin: Lessons from the poslparlum dairy cow. Proceedings of the New Zealand Society of Animal Production 64 19-23.

Lucy MC, McDougall S \& Nation DP 2004 The use of hormonal treatments to improve the reproductive performance of lactating dairy cows in feedlot or pasture-based management syslems. Animal Reproduction Science 82-83 495-512.

Lucy MC 2005 Non-lactational traits of importance in dairy cows and applications for emerging biotechnologies. New Zealand Veterinary lournal 53 406. 415.

Macmillan KL, Segwagwe BV \& Pino CS 2003 A550ciations between the manipulation of patterns of follicular development and fertility in cattle. Animal Reproduction Science 78 327-344.

Mann GE, Mann SJ, Blache D \& Webb R 2005 Metabolic variables and plasma leptin concentrations in dairy cows exhibiting reproductive cycle abnormalities identified through milk progesterone monitoring during the post partum period. Animal Reproduction Science 88 191-202.

Mann GE, Fray MD \& Lamming GE 2006 Effects of time of progesterone supplementation on embryo development and interferon-tau production in the cow. Veterinary Journal 171 500-503.

Mapletoft RJ, Lindsell CE \& Pawlshyn V 1986 Effects of clenbuterol, body condition, and nonsurgical embryo transfer equipment on pregnancy rates in bovine recipients. Theriogenology 25172 (abstract).

Mattos R, Staples CR, Thatcher WW 2000 Effects of dietary fatty acids on reproduction in ruminants. Reviews in Reproduction 5 38-45.

McDougall S 2003 Resynchrony of previously anoestrous cows and treatment of cows not detected in oestrus that had a palpable corpus luteum with prostaglandin F2 alpha. New Zealand Veterinary Journal 51 117-124.

McDougall S, Blache D, Rhodes FM 2005a Factors affecting conception and expression of oestrus in anoestrous cows treated with progesterone and oestradiol benzoate. Animal Reproduction Science 88 203-214.

McDougall S, Rhodes FM \& Verkerk G 2005b Pregnancy loss in dairy cattle in the Waikato region of New Zealand. New Zealand Veterinary Journal 53 279-287.

McDougall S \& Compton C 2006 Reproductive performance in the subsequent lactation of dairy cows previously treated for failure to be delected in oestrus. New Zealand Veterinary Joumal 54 132-140.

McDougall S, Macaulay R \& Compton C 2006 Association between endometritis diagnosis using a novel intravaginal device and reproductive performance in dairy cattle. Animal Reproduction Science (in press).

McNeill RE, Diskin MG, Sreenan JM \& Morris DG 2006a Associations between milk progesterone concentration on different days and with embryo survival during the early luteal phase in dairy cows. Theriogenology 65 1435-1441.

McNeill RE, Sreenan IM, Diskin MG, Cairns MT, Fitzpatrick R, Smith TJ \& Morris DG 2006b Effect of systemic progesterone concentration on the expression of progesterone-responsive genes in the bovine endometrium during the early luteal phase. Reproduction Fertility and Development 18573 . 583.

Meyer IP, Verkerk GA, Gore PJ, Macdonald KA, Holmes CW \& Lucy MC 2004 Effect of genetic strain, feed allowance, and parity on interval to first ovulation and the first estrous cycle in pasture-managed dairy cows. Journal of Animal Science 82 (Supplement 1) 66 (abstract).

Meyer JP, Radcliff RP, Rhoads ML, Bader JF, Murphy CN \& Lucy MC 2006 Timed Artificial Insemination of Two Consecutive Services in Dairy Cows Using Prostaglandin $\mathrm{F} 2 \alpha$ and Gonadotropin-releasing Hormone lournal of Dairy Science (in press).

Miyamoto A, Shirasuna K, Hayashi KG, Kamada D, Awashima C, Kaneko E, Acosta TJ \& Matsui M 2006 A potential use of color ultrasound as a tool for reproductive management: New observations using color ultrasound scanning that were not possible with imaging only in black and white. Journal of Reproduction and Development 52 153-160.

Miyoshi S, Pate II \& Palmquist DL 2001 Effects of propylene glycol drenching on energy balance, plasma glucose, plasma insulin, ovarian function and conception in dairy cows. Animal Reproduction $5 \mathrm{ci-}$ ence 68 29-43.

Moore K \& Thatcher WW 2006 Major advances associated with reproduction in dairy cattle. lournal of Dairy Science 89 1254-1266.

Opsomer G, Gröhn YT, Hertl J, Coryn M, Deluyker H \& de Kruif A 2000 Risk factors for post partum ovarian dysfunction in high producing dairy cows in Belgium: a field study. Theriogenology $53841-857$.

Petersson KJ, Gustafsson H, Strandberg E \& Berglund B 2006 Atypical progesterone profiles and fertility in Swedish dairy cows. Journal of Dairy Science $\mathbf{8 9}$ 2529-2538. 
Pierson RA \& Ginther OJ 1984 Ultrasonography of the bovine ovary. Theriogenology 21 495-504.

Pryce JE, Coffey MP, Brotherstone SH \& Woolliams JA 2002 Genetic relalionships between calving interval and body condition score conditional on milk yield. Journal of Dairy Science 85 1590-1595.

Pryce JE \& Harris BL 2006 Genetics of body condition score in New Zealand dairy cows. Journal of Dairy Science 89 4424-4432.

Rabiee AR, Lean IJ \& Stevenson MA 2005 Efficacy of Ovsynch program on reproductive performance in dairy cattle: a meta-analysis. Journal of Dairy $5 \mathrm{ci}$ ence 88 2754-2770.

Rhodes FM, McDougall S, Burke CR, Verkerk GA \& Macmillan KL 2003. Inviled review: Treatment of cows with an extended postpartum anestrous interval. Journal of Dairy Science 86 1876-1894.

Robinson RS, Hammond AJ, Nicklin LT, Schams D, Mann GE \& Hunter MG 2006 Endocrine and cellular characteristics of corpora lutea from cows with a delayed post-ovulatory progesterone rise. Domestic Animal Endocrinology 31 154-172.

Roche JF, Mackey D \& Diskin MD 2000 Reproductive management of postpartum cows. Animal Reproduction Science 60-61 703-712.

Roche JR, Berry DP \& Kolver ES 2006 Holstein-Friesian strain and feed effects on milk production, bodyweight and body condition score profiles in grazing dairy cows. Journal of Dairy Science $\mathbf{8 9}$ 3532-3543.

Saacke RG, Dalton JC, Nadir S, Nebel RL \& Bame JH 2000 Relationship of seminal traits and insemination time to fertilization rate and embryo quality. Animal Reproduction Science 60-61 663-677.

Santos JEP, Thatcher WW, Chebel RC, Cerri RLA, Galvao KN 2004 The effecl of embryo death rates in catlle on the efficiency of estrus synchronization programs. Animal Reproduction Science 82-83 513 535 ,

Sartori R, Sartor-Bergfelt R, Mertens SA, Guenther IN, Parrish II \& Wiltbank MC 2002 Fertilization and early embryonic development in heifers and laclating cows in summer and lactating and dry cows in winter. Journal of Dairy Science 85 2803-2812.

Sartori R, Gumen A, Guenther IN, Souza AH, Caraviello DZ \& Wiltbank MC 2006 Comparison of artificial insemination versus embryo iransfer in lactating dairy cows. Theriogenology 65 1311-1321.

Schafer DJ, Bader JF, Meyer IP, Haden JK, Ellersieck MR, Smith MR, \& Patterson DJ 2005 A comparison of progestin-based protocols to synchronize ovulation prior to fixed-time artificial insemination in postpartum beef cows. Journal of Animal Science $\mathbf{8 3}$ (Supplement 1) 85 .

Sewalem A, Kistemaker GJ, Miglior F \& Van Doormaal B) 2006 Analysis of inbreeding and its relationship with functional longevity in Canadian dairy cattle. journal of Dairy Science 89 2210-2216.

Silke V, Diskin MG, Kenny DA, Boland MP, Dillon P, Mee JF \& Sreenan JM 2002 Extent, pattern and factors associated with late embryonic loss in dairy cows. Animal Reproduction Science 71 1-12.

Snijders SE, Dillon P, O'Callaghan D \& Boland MP 2000 Effect of genelic merit, milk yield, body condition and laclation number on in vitro oocyte development in dairy cows. Theriogenology 53 981-989.

Starbuck GR, Gutierrez CG, Peters AR \& Mann GE 2006 Timing of follicular phase events and the postovulatory progesterone rise following synchronisation of oestrus in cows. Veterinary lournal 172 103-108.

Sterry RA, Welle ML \& Fricke PM 2006 Effecl of interval from limed artificial insemination to initiation of resynchronization of ovulation on fertility of lactating dairy cows. Journal of Dairy Science $\mathbf{8 9} 2099$ 2109.

Stevenson JS \& Phatak AP 2005 Inseminations at estrus induced by presynchronization before application of synchronized estrus and ovulation. Journal of Dairy Science 88 399-405.

Stevenson JS, Pursley JR, Garverick HA, Fricke PM, Kesler DI, Ottobre JS \& Wiltbank MC 2006 Treatment of cycling and noncycling laclating dairy cows with progesterone during Ovsynch. Journal of Dairy Science 89 2567-2578.

Stockdale CR 2001 Body condition at calving and the performance of dairy cows in early lactation under Australian conditions: a review. Austrafian fournal of Experimental Agriculture 41 823-839.

Stronge AJ, Sreenan JM, Diskin MG, Mee JF, Kenny DA \& Morris DG 2005 Post-insemination milk progesterone concentration and embryo survival in dairy cows. Theriogenology 64 1212-1224.

Taylor VJ, Cheng Z, Pushpakumara PG, Beever DE \& Wathes DC 2004 Relationships belween the plasma concentrations of insulin-like growth factor-1 in dairy cows and their fertility and milk yield. Veterinary Record 155 583-588.

Thatcher WW, Guzeloglu A, Mattos R, Binelli M, Hansen TR \& Pru JK 2001 Uterinc-conceplus interactions and reproductive failure in cattle. Theriogenology 56 1435-1450.

Thatcher WW, Moreira F, Pancarci SM, Bartolome JA \& Santos JE 2002 Strategies to optimize reproductive efficiency by regulation of ovarian function. Domestic Animal Endocrinology 23 243-2.54.

Thatcher WW, Bilby TR, Bartolome IA, Silvestre F, Staples CR \& Santos JE 2006 Strategies for improving fertility in the modern dairy cow. Theriogenology 65 30-44.

Vanholder T, Leroy JL, Soom AV, Opsomer G, Maes D, Coryn M \& de Kruif A 2005 Effect of non-esterified fatty acids on bovine granulosa cell steroidogenesis and proliferation in vitro. Animal Reproduction Science 87 33-44.

Vanholder T, Opsomer G \& de Kruif A 2006 Aetiology and pathogenesis of cystic ovarian follicles in dairy catlle; a review. Reproduction Nutrition and Devefopment 46 105-119.

VanRaden PM, Sanders AH, Tooker ME, Miller RH, Norman HD, Kuhn MT \& Wiggans GR 2004 Development of a national genetic evaluation for cow 
fertility. Journal of Dairy Science $\mathbf{8 7}$ 2285-2292.

VanRaden PM 2006 Fertility trait economics and correlations with other traits. Interbull Annual Meeting Proceedings. Interbull Bulletin 34 53-56.

VanRaden PM \& Miller RH 2006 Effects of nonadditive genetic interactions, inbreeding, and recessive defects on embryo and fetal loss by seventy days. Journal of Dairy Science 89 2716-2721.

Vasconcelos IL, Demetrio DG, Santos RM, Chiari JR, Rodrigues CA \& Sa Filho OG 2006 Factors potentially affecting fertility of lactating dairy cow recipients. Theriogenology 65 192-200.

Watson AJ, Westhusin ME \& Winger QA 1999 IGF paracrine and autocrine interactions between conceptus and oviduct. lournal of Reproduction and Fertility Supplement $\mathbf{5 4}$ 303-315.
Weigel KA \& Rekaya R 2000 Genetic parameters for reproductive traits of Holstein cattle in California and Minnesota, Journal of Dairy Science $\mathbf{8 3} 1072$. 1080.

Williams GL \& Griffith MK 1995 Sensory and behavioral control of gonadotrophin secrefion during suckling-mediated anovulation in cows. Journal of Reproduction and Fertility Supplement 49 463-475.

Wiltbank MC, Gumen A \& Sartori R 2002 Physiological classification of anovulatory conditions in cattle. Theriogenology 57 21-52.

Wiltbank M, Lopez H, Sartori R, Sangsritavong S \& Gumen A 2006 Changes in reproductive physiology of lactating dairy cows due to elevated steroid metabolism. Theriogenology 65 17-29. 